\title{
New Bioethical Challenges Related to the COVID-19 Pandemics. A Look from the Perspective of the Polish Legal Regulations
}

\author{
Anna Paprocka Lipińska* and Grzegorz Graff \\ Department of Medical Ethics, Medical University of Gdańsk, Poland
}

Corresponding author: Anna Paprocka Lipińska, Head of the Department of Medical Ethics, Medical University of Gdańsk, 80-210 Gdańsk, Tuwima str 15, Poland

\begin{tabular}{|c|c|}
\hline ARTICLE INFO & ABSTRACT \\
\hline Received: 幽 October 17, 2020 & Citation: Anna Paprocka Lipińska, Grzegorz Graff. New Bioethical Challenges Related to \\
\hline Published: 蔧 October 27, 2020 & $\begin{array}{l}\text { the COVID-19 Pandemics. A Look from the Perspective of the Polish Legal Regulations. } \\
\text { Biomed J Sci \& Tech Res 31(3)-2020. BJSTR. MS.ID.005101. }\end{array}$ \\
\hline
\end{tabular}

\section{Opinion}

In every country, the burden of fighting the pandemic lies on the shoulders of healthcare professionals. However, the actual course of this battle is conditioned by the epidemic management strategies introduced by the authorities and state institutions. Today we can see clearly how the differences in the organization of public healthcare in various countries may influence the arising bioethical problems and the attempts at solving them. One of the problems is the acceptance of the new risk, potential infection with SARS-CoV-2 at work, by healthcare professionals. This issue had been earlier discussed in the countries affected by SARS virus, which was a new danger for the medical staff. Writing about the lesson from the epidemic of SARS in 2003, Emanuel reaches to the core of medical ethics, that is the ethical obligation to act for the patient's benefit, and emphasizes the need to make every healthcare professional aware of that obligation. He juxtaposes this bioethical challenge with the duties of the state institutions, the task of which is to organize healthcare in a way ensuring maximum protection of physicians and nurses at the frontline, and indicated the need to start a global debate on the topic with a view to possible epidemics in the future [1].

The risk related to epidemic-prone diseases and the duty to treat patients were discussed in a 2008 article by Dwyer and Tsai written after the SARS epidemic in Taiwan. The paper indicates that every healthcare professional should fulfil their professional duties in accordance with the law and the regulations of biomedical ethics, but, simultaneously, these duties should be organized "in a way that is both fair and efficacious" [2]. In various countries, there are similar ethical regulations based on the same universal rules collected in codes of conduct for medical professionals, revolving around the core idea of providing help to patients. In Poland, the currently binding Code of Physician's Ethics from 1991 (last amended in 2003) contains the same universal rules of medical ethics and does not provide specific regulations referring to extraordinary situations, such as an epidemic or pandemic [3]. We have not been affected by the epidemic of SARS so there was no debate on new ethical challenges related to an infectious disease that is potentially lethal also for the medical staff. However, in the Polish law there is an Act of 5 December 2008 on preventing and combating infections and infectious diseases among people [4].

Pursuant to Article 47 of this act, the state authorities may direct the employees of healthcare entities to fight the epidemic. The practical consequences of this legal regulation have already become an experience of many Polish physicians and nurses who, regardless of their experience and specialisation, were directed to work in the indicated places, with the orders brought by the police, often at night. The act does not oblige the employer to provide the employees directed to work this way with adequate personal protection equipment and reduce the exposure risk to minimum. This leads to a new question: should healthcare professionals 
accept any risk, even the risk that can be avoided by proper administrative decisions, to act for the benefit of the patients? Can healthcare professionals be forced (not only by referring to the general rules of biomedical ethics, but also by imposing penalties for refusal to exert their professional duties in the entities indicated by the state authorities) to risk their lives and lives of their family members in the situation when people and institutions responsible for work organization fail to fulfil their obligations and do not bear any consequences? It seems that such a force-based solution is difficult to accept both for physicians with many years of work experience and to those at the beginning of their professional career. Moreover, coercion, which naturally leads to resistance, has nothing in common with medical ethics. In our opinion, in the future, when the pandemics has ended, this situation may leave a negative mark on the perception of the physician's job, both by the society and the physicians themselves.

Another problem lying on the border of ethics and organization is deciding about the use of ICU treatment based not only on purely medical criteria, but also additional regulations. During the first stage of the pandemic, in many countries there was a debate about the need to formulate bioethical recommendations for making decisions about ICU treatment during the pandemic. In Spain, the discussion ended with a consensus; the recommendations were published and accepted by the society [5]. In Poland, for many years we have been witnessing a discussion about the lack of proper funding and irregularities in the organization of public healthcare. It provokes a question whether new extraordinary regulations limiting the already limited options of specialized ICU treatment may be suggested or recommended when the state institutions have not fulfilled their obligation of organizing the availability of such treatment in normal conditions, before the pandemic. In other words, we find it disturbing to note that such extraordinary regulations may serve as a permission for irregularities and questionable if they should be discussed at all.

\section{References}

1. Emanuel EJ (2003) The Lessons of SARS. Ann Intern Med 139: 589-591.

2. Dwyer J, Tsai D FC (2008) Developing the duty to treat: HIV, SARS, and the next epidemic. J Med. Ethics 34: 7-10.

3. Polish Code of Physician's Ethics.

4. (2008) Act of 5 December on preventing and combating infections and infectious diseases among people.

5. Rubio o, Estella A, Cabre L, Saralegui-Reta I, Martin MC, et al. (2020) Ethical recommendations for a difficult decision-making in intensive care units due to the exceptional crisis due to the COVID-19 pandemic: rapid review and consensus of experts. Med Intensiva 44(7): 439-445.

$\begin{array}{ll}\text { BIOMEDICAL } & \text { Assets of Publishing with us } \\ \text { RESEARCHES } & \text { - Global archiving of articles } \\ \text { - Immediate, unrestricted online access }\end{array}$

